\title{
The Impact of Adopting an Experiential Service Learning Group Project on Teaching Effectiveness
}

\author{
Reza Motameni*
}

\author{
The Department of Marketing and Logistics, California State University, Fresno. 5245 North Backer Avenue. Fresno, \\ CA 93740, USA
}

\begin{abstract}
It is a well-established fact that learning is facilitated when the student participates completely in the learning process and is confronted with practical problems. "Experiential Learning" occurs when students participate in some activity, reflect upon the activity, use their analytical skills to derive some useful insight from the experience, and then incorporate their new understanding(s) into real business situations. The incorporation of "Service Learning" which is using the "Experiential Learning" conceptual framework has become widespread in numerous colleges and universities. Nevertheless, while there has been a steady increase in the understanding of how service-learning affects students and communities, there remains a dearth of research on how using "Service Learning" pedagogy impacts faculty. Few studies have focused on the faculty side of "Service Learning". The literature review of this paper indicated a significant lack of any evidence that illustrates the impact of adopting a service learning project on a student's perception of an instructor's teaching effectiveness. The overall purpose of this article was to assess such impact. The result of this experimental study strongly suggests that inclusion of a "Service Learning" project in a marketing course, in addition to creating a unique and distinguishable factor in a student's mind regarding civic engagement, will positively change their perception of the instructor's teaching effectiveness too. The second conclusion is that the necessary resources including all relevant information, readings, guidelines, plans, and forms should carefully be created with easy access to them by students(e.g., via a website).
\end{abstract}

\section{INTRODUCTION}

In recent years, the discipline of marketing has received a lot of criticism regarding the type of education being offered to marketing undergraduates. Much of the criticism has been put forward by the business community. The criticisms include the lack of necessary skills to apply the theoretical concepts and abstract knowledge in practical situations. The Association to Advance Collegiate Schools of Business (AACSB) has also called for linking marketing concepts and theories with real-world business practices. It is a wellestablished fact that learning is facilitated when the student participates completely in the learning process and is confronted with practical problems. "Experiential Learning" philosophy has grown in popularity over the past twenty years. This type of learning occurs when students participate in some activity, reflect upon the activity, use their analytical skills to derive some useful insight from the experience, and then incorporate their new understanding(s) into real business situations.

The incorporation of "Service Learning" as an integral component of various types of business courses has become widespread in numerous colleges and universities (Hesser 1995 [1]), Klink, D.A. 2004 [2]). "Service Learning", which is using the "Experiential Learning" conceptual framework, is based on the idea that students learn best from involvement in experiential activities directly related to the

*Address correspondence to this author at the Department of marketing and Logistics, California State University, Fresno. 5245 North Backer Avenue. Fresno, CA 93740, USA; Tel: (559) 278-7830; Fax: (559) 278-8577;

E-mail: motameni@csufresno.edu course content and at the same time addressing community and societal needs (Sigmon 1994 [3]). The society expects that state supported colleges and universities contribute something meaningful to the local communities, since the tax payers subsidize a significant portion of real cost of the students education.

Driscoll, Holland, and Gelmon (1996 [4]) proposed a model of assessment to measure the impact of "Service Learning" on four constituencies consisting of student, faculty, community, and institution. Evangelopoulos, Sodorova, and Riolli (2003 [5]) conducted a longitudinal study involving undergraduate students. The results of their study indicated that students involved in "Service Learning" projects experienced significantly higher increase in their perception of the course material's usefulness relative to a comparison group. A significant number of other exploratory studies have been conducted on the use and benefits of service-learning projects in business courses (Hagenbuch 2006 [6]). The majority of studies, to greater extent, have focused on the value added impact of service learning for students, communities, and colleges and universities (see Table 2).

Nevertheless, while there has been a steady increase in the understanding of how service-learning affects students and communities, there remains a dearth of research on how using "Service Learning" pedagogy impacts faculty. It seems that research on "Service Learning" tends to emphasize students' learning outcomes and de-emphasize its impact on faculty. Driscoll (2000 [7]) has also suggested that the critical role of faculty with "Service Learning" is well documented, yet there is a paucity of research about the 
impact of service learning on faculty. Few studies have focused on the faculty side of "Service Learning". Hesser 1995 has focused on why faculties have moved from skepticism to forming a positive attitude regarding experiential education. His recommendations include: increased and immediate attention and resources be focused on research related to motivations and attractions of faculty to service-learning; impacts or influences of service-learning on faculty; satisfactions reported by faculty; and the difficulties, obstacles, and challenges faced by faculty engaged in "Service Learning". Abes, Jackson, and Jones (2002 [8]) tried to determine the factors that motivate and deter faculty use of "Service Learning". Their findings indicated remarkable consistency in motivators and deterrents to "Service Learning" use, both for faculty who do and do not use service learning. Pribbenow (2005 [9]) in his research study discovered six themes that illuminated how using this "Service Learning" pedagogy shaped and influenced faculty members' understandings of, and approaches to teaching and learning.

\section{THE OVERALL PURPOSE OF THIS ARTICLE}

The literature review of this paper indicated a significant lack of any evidence that illustrates the impact of adopting a service learning project on a student's perception of an instructor's teaching effectiveness. The overall purpose of this article is to assess such impact. It should be noted that using comprehensive hands-on types of projects related to the content of a course for Community-based Organizations (CBOs) is widely used in American universities, particularly if the mission statement of a school or a department specifies that the school and the department are offering an applied educational program while engaging its constituencies such as faculty, students and staff in community services. This article is presenting the findings of adopting a service learning project in the principles of marketing course offered by a state-supported university in United States.

Part II of this paper discusses the relevant conceptual frameworks including the key concepts behind "Peirce \& James "Pragmatism", "Dewey's Philosophy of Education", "Experiential Learning Cycles", David Kolb's Experiential Learning Model, "Problem-based Learning", "Learning by Sharing/Developing \& Collaborating" and their relationships (see Fig. 2). The "Service Learning" concept and its evolutionary boundary expansion and its benefits for a variety of constituencies will be discussed too. Part III presents the broadly accepted definitions of service learning, Part IV discusses the service learning benefits, Part V. presents the "Research Design" used in this study to measure the impact of adopting a "Service Learning" project on teaching effectiveness, Part VI presents the quantitative findings, Part VII presents the "discussion (Qualitative) findings", and finally Part VIII is designated to the "Conclusions".

\section{The Conceptual Frameworks}

\section{A. Peirce \& James Pragmatism}

Pragmatism considered as a philosophical movement consisting of varying but connected theories developed by Charles S. Peirce (1966 [10]) and William James (1995 [11]) and later taken up and transformed by John Dewey (1963
[12]) is characterized by the doctrine that the meaning of an idea or a proposition lies in its observable practical consequences. Pragmatists emphasize the practical function of knowledge as an instrument for adapting to reality and controlling it. According to Stuhr (2000 [13]), the experiential learning conceptual frameworks have their roots in the key concept of "pragmatism". William James recognized Charles Sanders Peirce as one of the originators of "pragmatism". Stuhr regarded two of Peirce's papers, "The Fixation of Belief", and "How to Make Our Ideas Clear", among others, as pragmatism's origin. Peirce's work in logic helped establish the philosophical school of thought known as "pragmatism" which is a method of sorting out conceptual confusions by equating the meaning of any concept with the conceivable operational or practical consequences of that concept. Peirce conceived pragmatism as a method for clarifying the meaning of difficult ideas through application of the pragmatic maxim. Later on, the ideas behind "pragmatism" was developed and transformed further by William James and John Dewey. William James generalized the theories of Charles Sanders Peirce to assert that the meaning of any idea must be analyzed in terms of the succession of experiential consequences to which it leads, in other words "pragmatism" emphasized the practical function of knowledge.

\section{B. Dewey's Philosophy of Education}

Dewey (1963 [12]) was the most famous proponent of hands-on learning or experiential education. Dewey's philosophy of education was centered on the supposition that people learn the best experientially and that some experiences are instructive at the same time as others are not. All experiences are understood to be "continuous", that is, each experience influences future experiences. He also emphasized the subjective nature of experience, implying that the educators must be constantly alert to student's uniqueness in terms of background of the participants, and personality, and learning styles. He advocated that, it is the teacher's responsibility to structure and organize a series of experiences which positively influence each individual's potential future experiences because "good experiences motivate", encourage, and enable students to go on to have more valuable learning experiences, whereas, "poor experiences" tend to lead towards a student closing off from potential positive experiences in the future. Dewey believed that the school should teach students how to be problemsolvers by helping students learn how to think rather than simply learning rote lessons about large amounts of information (Dewey 1963 [12]).

\section{Experiential Learning Cycles}

According to Neill (2004 [14]) Experiential Learning Cycles are models for understanding how the process of learning works. They are distinct from other models of learning in two notable ways. First "Experiential Learning Cycles" treat the learner's subjective experience as of critical importance in the learning process, and secondly they draw on experiential education principles, which are largely based on the educational philosophy of John Dewey. Experiential Learning Cycles propose an iterative series of processes which underlies learning. Depending on the model, there is anywhere between one stage (experience alone) through to 
Table 1. Experiential Learning Cycles

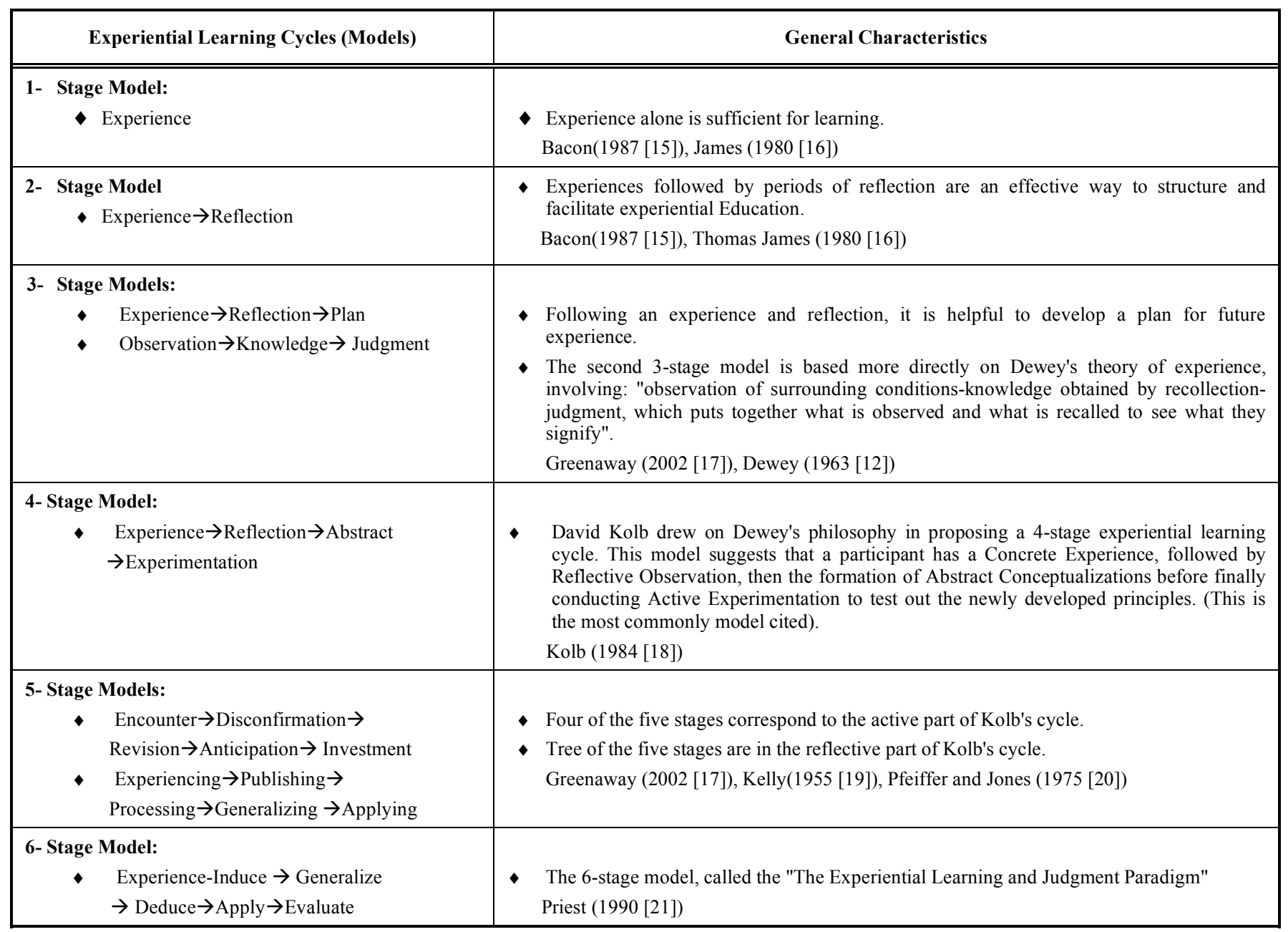

six stages of learning to be considered. Neill (2004 [14]) has identified numerous "Experiential Learning Cycle" models in experiential learning literature that can be organized in terms of the number of stages they propose (See Table 1).

\section{David Kolb’s Experiential Learning Model}

David A. Kolb helped to popularize the idea of experiential learning drawing heavily on the work of John Dewey (1963 [12]. His work on experiential learning has contributed greatly to expanding the philosophy of experiential education. David Kolb (1984 [18]) developed the most established model of "Experiential Learning". In his model the process begins with an experience (knowledge by doing), followed by reflection (concentrating on what the experience means to the experiencer). The reflection then leads to conceptualization (knowledge about, which is theoretical and is represented by abstract concepts), and finally applying the new knowledge in real situations. Because "Experiential Learning" engages students, its benefits include: increased learning, motivation, and connection to reality. In "Experiential Learning" students participate actively, rather than passively in their education. According to Eyler \& Giles (1999 [22]) "Service Learning" is a form of "Experiential Learning" where learning occurs through a cycle of action and reflection as students work with others through a process of applying what they are learning to community problems and, at the same time, reflecting upon their experience. In the process, students link personal and social development with academic and cognitive development because experience enhances understanding; understanding leads to more effective action. Fig. (1) depicts the David Kolb's Experiential Learning Model

\section{E. Problem-Based Learning}

Problem-based learning (PBL) is a learning situation when students work cooperatively with each other, in small collaborative groups, to seek solutions to real world problems. The Students will be given a problem before learning some knowledge. The problem is posed in order to motivate students to discover that they need to learn some new knowledge before they are able to solve the problem. PBL is any learning environment in which the problem drives the learning. PBL prepares students to think critically and analytically and fosters the development of communication, problem-solving, and self-directed learning skills. The role of the instructor will be to guide the learning process rather than provide knowledge (Hmelo-Silver \& Barrows, 2006 [23], Merrill, 2002 [24]), in other words PBL is a learner-centered rather than an instructor-centered approach, in which the problem situation drives the learning. 


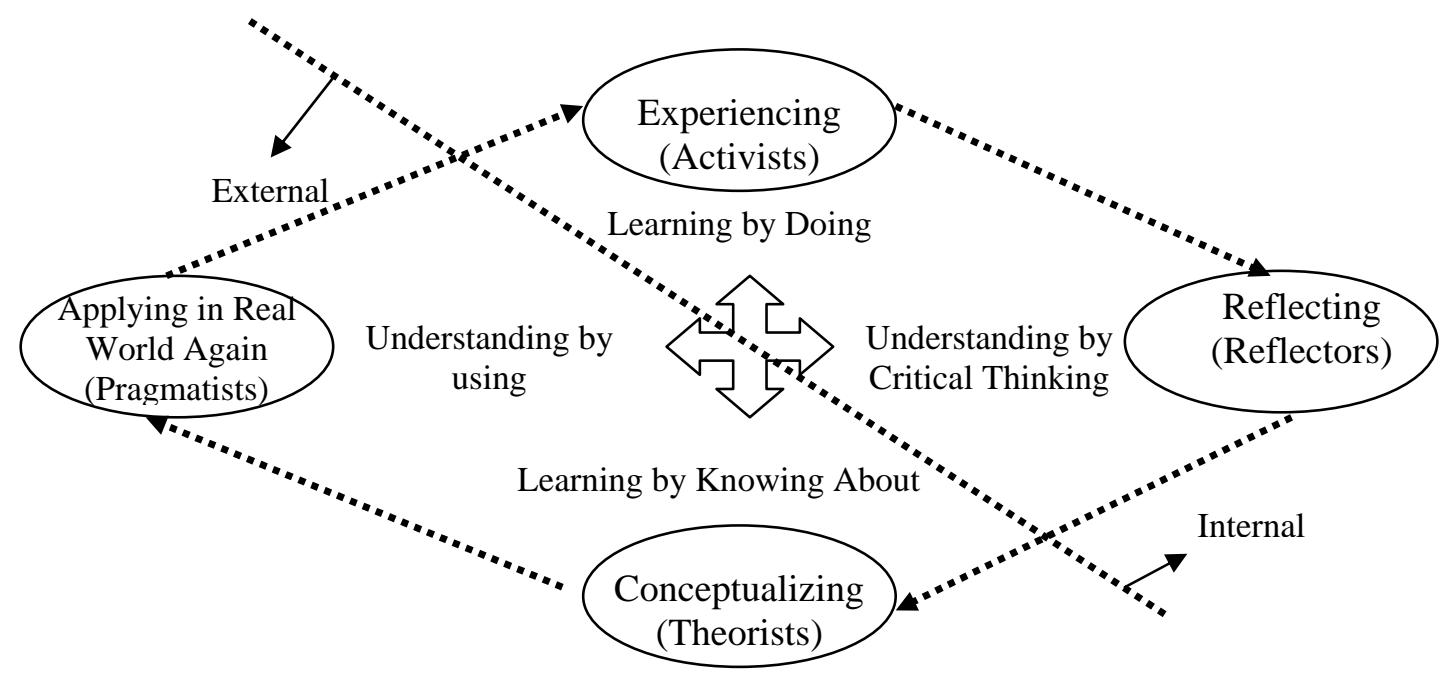

Fig. (1). Two ways of learning and understanding.

PBL was pioneered and used extensively at McMaster University (Ontario, Canada) in the 1970s. The university became renowned for its use of its non-traditional smallgroup problem-based learning method in the field of Health Sciences, PBL has since been adopted in other disciplines including business, education, law, nursing, and engineering. Unlike traditional lecture-based instruction, where information is passively transferred from instructor to student, PBL students are active participants in their own learning, thrusted into unknown learning situations where the parameters of the problem may not be well-defined and the task at hand ambiguous-just like in the real world. Research shows PBL provides students with skills that are critical for lifelong learning, such as critical thinking, problem-solving, teamwork, and the ability to apply their knowledge to new situations (Massa 2008 [25]).

Based on more than three decades of research on effective educational principles and practices, Bransford et al. (2000 [26]) recommended that to be effective, educators must first draw out and engage students' preconceptions regarding their understanding about how the world works. Second, in order for students to develop competence in a particular subject area, they must develop a deep foundation of factual knowledge, understand that knowledge in the context of a conceptual framework and organize it in a way that facilitates retrieval and application. Finally, instruction must facilitate the development of students' metacognitive skills; skills needed to take responsibility for planning, monitoring, and evaluating their own learning. With PBL, each of these steps is addressed through engagement in the problem-solving process, in other words PBL is consistent with the recommendations outlined by John Bransford and his colleagues (Massa 2008 [26], Spronken-Smith and Tony Harland 2009 [27]).

\section{F. Learning by Sharing/Developing \& Collaborating}

Some newer and emerging concepts dealing with the essence of experiential learning include "Learning by Sharing", "Learning by Developing", and "Collaborative Learning". According to Bjerkaker (2006 [28]) "Learning by Sharing" is a method that offers opportunities and possibilities for all participants to contribute their previous knowledge and experiences through open and democratic dialogue, in order collectively to develop the knowledge further among the participants. Collaborative Learning refers to learning processes in which learning takes place in a small group with an interactive social environment through cooperative processes for common academic purposes and shared learning tasks (Alderman 2000 [29], Gokhale 1995 [30], Mukaddes 2009 [31]). Collaborative learning processes emphasize searching for and constructing common meaning beyond individual knowledge and subjective meaning while working cooperatively on the same learning tasks (Kumpulainen and Kaartine, 2003 [32]). In this type of learning, students work collaboratively on a real problem over a relatively long period of time, making use of a variety of resources which enable them to realize various cognitive processes such as gathering, organizing, and evaluating relevant information.

Fig. (2) depicts the interrelationships and connectedness of conceptual frameworks discussed above. It is clear that Peirce and James conceptualization of "Pragmatism" led to conclusion by Dewey's that people learn the best experientially, which in turn led to the development of "Experiential Learning Cycles (Models). The combined impact of Dewey's and Kolb's contribution led to emergence of "Problem-based Learning". The information technology revolution had made it possible the "Learning by 


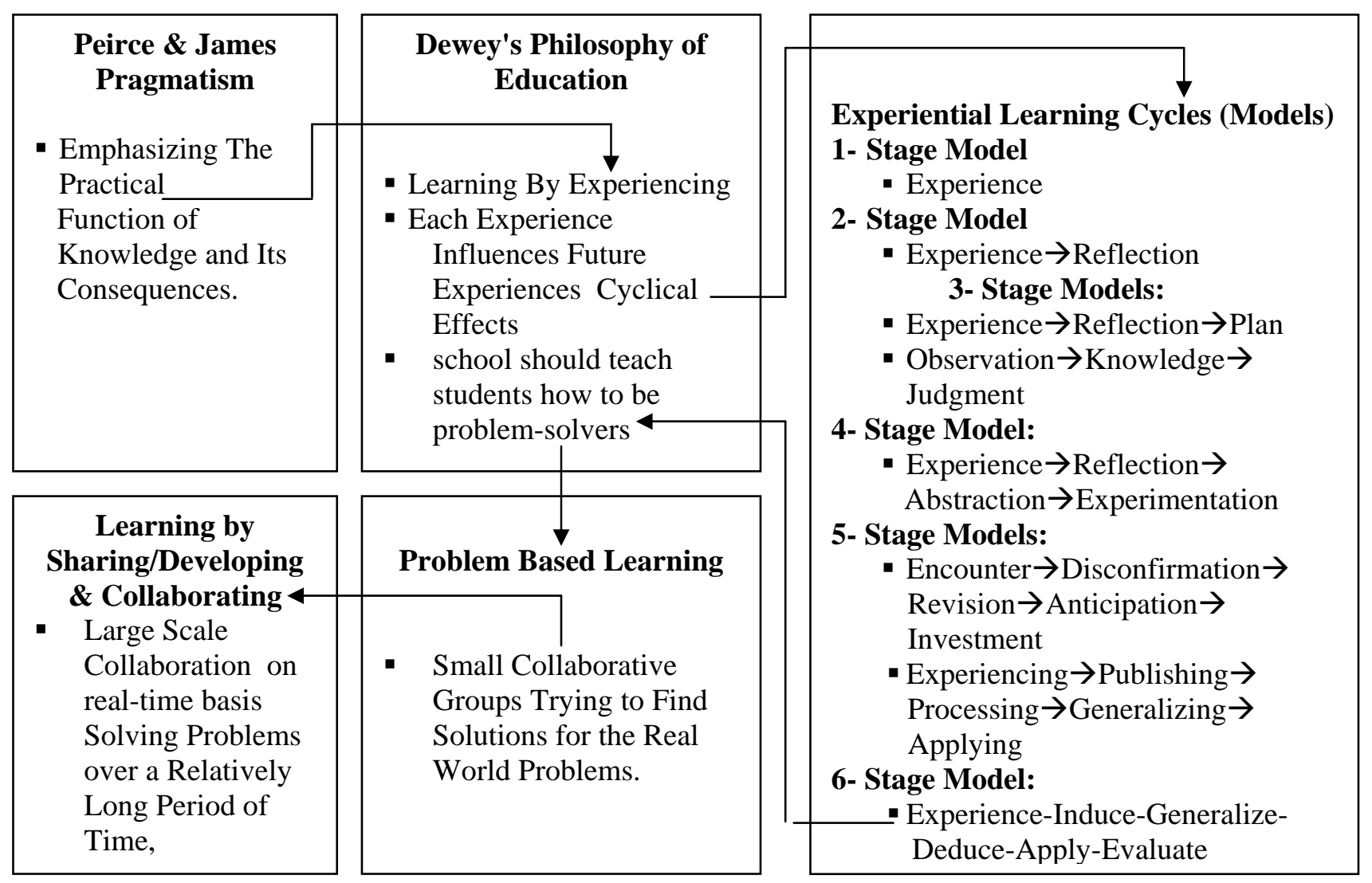

Fig. (2). The interrelationships and connectedness of conceptual frameworks.

Sharing/Developing \& Collaboration" on real time basis becomes a reality.

\section{G. The "Service Learning” Historical Background}

According to National Service-Learning Clearinghouse [33] (see Fig. 3), the community service and civic engagement have a long history. In 1960's the formation of the Peace Corps and Volunteers in Service to America (VISTA) had an enduring presence on campuses. During this time period the early pioneers of the service-learning movement began to emerge and attempted to combine 'service' to 'learning' in a direct way. In the early to mid 1980 s a resurgence of interest in campus service and servicelearning took place, with a national initiative to promote service among undergraduate students. National service efforts were launched across the country, including the Campus Outreach Opportunity League (1984), the National Association of Service and Conservation Corps (1985), National Youth Leadership Council (1982), and Youth Service America (1985). The National and Community Service Act of 1990, authorized grants for schools colleges, and universities to support service-learning. The present moment of renewed attention to the civic mission of universities has been called the "fourth wave" of higher education civic engagement initiatives. This wave is a forward-looking vision at the future of higher-education itself. The movement goes significantly beyond efforts to bring civic engagement to individual classrooms. Instead there is a push toward a fully-engaged university as a whole: active, vibrant partnerships of scholars, as well as students and citizens who have the support and resources to achieve phenomenal things in education and in transforming communities nationwide. Fig. (3) depicts the evolutionary path of "Service Learning".

\section{BROADLY ACCEPTED DEFINITIONS OF "SERVICE LEARNING"}

Sigmon (1979) [34] attempted to provide a definition of "Service Learning" through a typology that compares different programs that combine service and learning. Each service program lies on the continuum which is determined by its primary intended beneficiary and its overall balance between service and learning. As Fig. (4) suggests different types of service programs can be distinguished by their primary intended "Beneficiary" and "Focus".

"Volunteerism" is the engagement of students in activities where the primary emphasis is on the service being provided and the primary intended beneficiary is clearly the service recipient. "Community Service" is the engagement of students in activities that primarily focus on the service being provided as well as the benefits the service activities have on the recipients. "Internships" on the opposite side of the continuum, engage students in service activities primarily for the purpose of providing students with hands-on experiences that enhance their learning or understanding of issues relevant to a particular area of study. "Field Education" programs provide students with co-curricular service opportunities that are related, but not fully integrated, with their formal academic studies. "Service Learning" goes 


\begin{tabular}{|c|c|c|c|}
\hline $\begin{array}{l}\text { 1960s: the } \\
\text { Emergence of } \\
\text { Service- } \\
\text { Learning } \\
\text { Movement } \\
\\
\text { Formation of } \\
\text { the Peace } \\
\text { Corps } \\
\text { Volunteers in } \\
\text { Service to } \\
\text { America } \\
\text { (VISTA) }\end{array}$ & $\begin{array}{l}\text { 1980s: } \\
\text { Revitalization } \\
\text { - the Campus } \\
\text { Outreach } \\
\text { Opportunity } \\
\text { League } \\
\text { The Notational } \\
\text { Association of } \\
\text { Service and } \\
\text { Conservation } \\
\text { Corps }\end{array}$ & $\begin{array}{l}\text { 1990s: Government } \\
\text { Grants Authorization } \\
\text { Era } \\
\text { the Office of National } \\
\text { Service } \\
\text { the Points of Light } \\
\text { Foundation } \\
\text { the National and } \\
\text { Community Service } \\
\text { Act of } 1990 \\
\text { Learn and Serve } \\
\text { America }\end{array}$ & $\begin{array}{l}\text { 2000s: a Fully } \\
\quad \text { Engaged } \\
\text { University Era } \\
\\
\text { Partnerships of } \\
\text { Scholars, } \\
\text { Students and } \\
\text { Citizens } \\
\text { Transforming } \\
\text { Communities }\end{array}$ \\
\hline
\end{tabular}

Fig. (3). THE evolutionary path of "service learning".

beyond volunteerism. "Service Learning" is distinguished from other approaches to experiential education by equally benefiting both the provider and the recipient of the service as well as to ensure equal focus on both the service being provided and the learning that is occurring.

"Service Learning" is an academic study linked to community service through structured reflection so that each reinforces the other (Kendall 1990 [35], Furco 1996 [36], Govekar, and Meemakshi 2007 [37]). The National Society for Experiential Education (1994) [38] broadly defines "Service Learning" as: "Any carefully monitored service experience in which a student has intentional learning goals and reflects actively on what he or she is learning throughout the experience". Even though there are numerous conceptualization of "Service Learning", there is a core concept upon which all seem to agree: "Service Learning" combines service objectives with learning objectives with the intent that the activity changes both the recipient and the provider of the service. This is accomplished by combining service tasks with structured opportunities that link the task to self-reflection, self-discovery, and the acquisition and comprehension of values, skills, and knowledge content. Petkus 2007 [39] has reinforced the above arguments by stating that: "experiential learning opportunities that expose students to cross-cultural marketing situations rather than relying solely on textbook descriptions may be successfully achieved through the Service Learning" project.

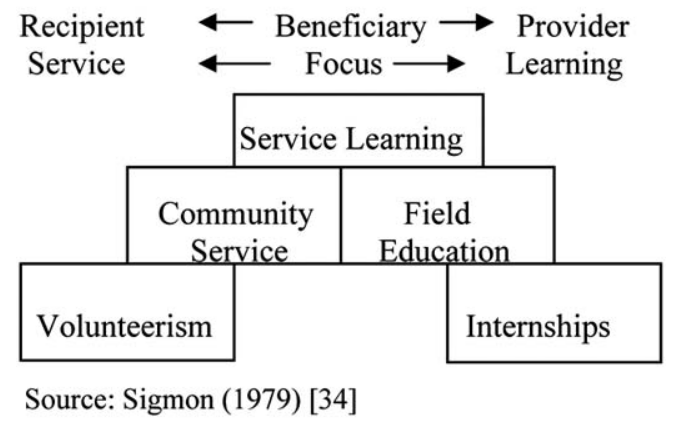

Fig. (4). Continuum of service types.

\section{IV. "SERVICE LEARNING" BENEFITS}

Survey research over the past decade gives us ample evidence of the impact of "Service Learning" on the personal and social development of college students. Significant research about the effectiveness of Service Learning" has been conducted for over two decades. These studies include surveys of thousands of students at colleges and universities throughout the country (Eyler 2000 [40], Eyler et al., 2001 [41]). The findings support the conclusion that students who complete a quality "Service Learning" assignment that is connected to the course curriculum, experience several advantages compared to students in courses that do not use Service Learning". According to Shaw (2007 [42]) "Service Learning" has provided numerous skills to participating students including reading, writing, public speaking, critical thinking, self-confidence, self-esteem, and self-reflection. Lopez and Lee (2005 [43]) believe there exists further benefit of participation in a client-based project by applying their marketing knowledge accumulated in the classroom to the needs of a real world client. Eyler, et al. (2001) [41] have summarized the findings of multitudes of studies which indicated "Service Learning" has provided many concurrent benefits to multiple participants including students, universities, and communities. For the summaries of their findings, and updated findings (by the author of this article) refer to Table 2 .

\section{THE RESEARCH DESIGN}

As Table 2 points out numerous researches have been conducted on the uses and benefits of "Service Learning" for various constituencies. However, the evidence that illustrates the impact of "Service Learning" project on student's perception of an instructor's teaching effectiveness has been lacking. The overall purpose of this study was to encompass that disparity. Cone 2001 [62] identifies six models of service-learning, two of which are appropriate for principles of marketing type of courses: the Discipline-Based ServiceLearning (DBSL) and the Problem-Based Service-Learning (PBSL) models. The PBSL model is more of a project-based activity where individuals or groups of students act as consultants to the community organization by working on a specific problem or issue. Using the PBSL model, an experimental type of study was conducted to assess the impact of incorporating a service learning project on students' perception of the instructor's teaching effectiveness.

Fig. (5) schematically presents the research methodologies used in this study. Both quantitative (the Static Comparison Design), and qualitative methods (Focus Group Analysis, 


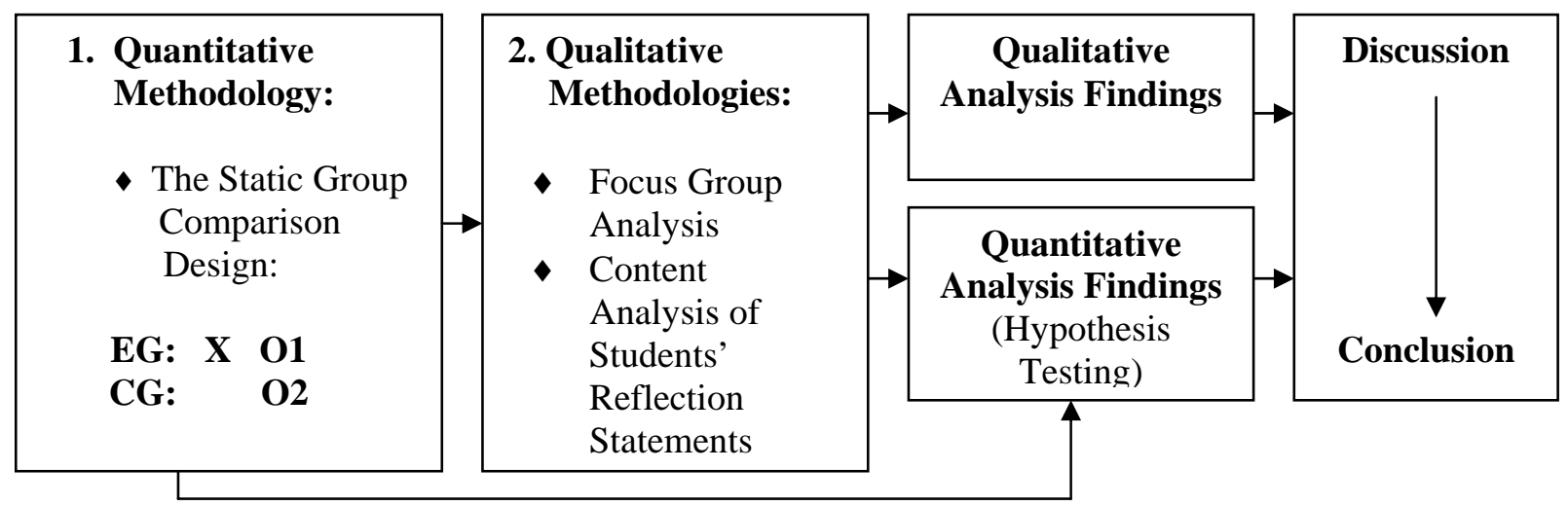

Fig. (5). The research design.

and Content Analysis) were utilized. The quantitative methodology was used to statistically determine the student's perception regarding the impact of including the Problem-Based Service-Learning (PBSL) group project on the instructor's teaching performance. After the quantitative analysis was performed a focus group study was conducted in order to validate the results and give an opportunity to students to share their opinions about quantitative findings. In addition, since the PBLS group project required all students to write two-page "Reflection" after they have finished their project, a "Content Analysis" was performed on student's reflections. The result of focus group study and content analysis helped the author of this article to elaborate on findings in "Discussion" and "Conclusion" sections of this paper. The following section provides detail information about research methodologies used in this study.

\section{Quantitative Methodology}

\section{The Static Group Comparison Design}

During four semesters (two academic years), eight sections of a principle of marketing classes taught by the author of this article. Everything in these sections were identical including common learning objectives, learningoutcome, exams, syllabus, and text book. Four sections of classes consisted of 160 students were designated as Experimental Group (EG). In those four sections a ProblemBased Service-Learning (PBSL) group project was assigned as the primary project of the course, equivalent to $25 \%$ of the total grade. Four other sections, consisted of 145 students, were designated as the Control Group (CG). In those four classes the (PBSL) project was not used. Since everything else was equal in all sections with the exception of the PBSL project occurrence in EG, any changes in perception of students regarding teaching effectiveness should rationally and logically be attributed to the impact of PBSL project. The Static Group Comparison Design used in this study may be symbolically presented as:

EG: X O1

CG: $\mathrm{O} 2$

\section{Where:}

01 \& 02: students' perception of instructor's teaching effectiveness
X (Treatment): participating in the Problem-Based ServiceLearning (PBSL) group project:

The Static Group Comparison Design is a design in which there are two groups, one that has experienced the treatment $(\mathrm{X})$ is called the "Experiment Group", and another that has not is called "Control Group". students' perception of instructor's teaching effectiveness was measured at the end of each semester (O1 and O2). The experimental sections of the course were designated as a "Service Learning" class where students learned the basic principles and marketing tools. The students were required to engage in community service while relating that experience to classroom material. Marketing is an ideal business discipline for using the PBSL group project since most nonprofit organizations can use assistance in this area. The PBSL group project was completed by teams of five students.

With the approval of the course instructor each student was committed to serving a minimum of 15 hours with a non-profit or a government supported Community-Based Organization (CBO). The teams agreed to provide solutions to a specific set of problems that the organization were facing. The project included clearly defined purpose and outcomes. The project was mandated that the problem and issues should be related to some aspects of marketing. Staff members of each CBOs were available to assist and provide guidance to students regarding their respective PBSL group projects. The teams were provided an overall orientation at the organization's base of operation, but portions of the actual work on the project could be performed away from the agency. The PBSL group project was consisted of four interrelated components:

Reading Assignments: two articles were assigned to make the students familiarize with concept of servicelearning: Allison and Kaye 2000 [83]: "Eight Characteristics of Nonprofit Organizations" and "Service Learning Everybody Wins!" Then students were required to write a report discussing: A) The similarities and difference between for-profit and not-for-profit marketing, B) What is service learning and how does it differ from volunteerism and community service, C) Why do they think that business students can benefit from a service-learning type of experience? 
Table 2. Service Learning Benefits

\section{Value Added Impacts}

Recipient of Benefits: Students

Personal outcomes:

1. Service-learning can help students to improve academically, research has shown that:

A. Students who participate in high quality service-learning experiences typically become more engaged in learning as shown by increased attendance and motivation to learn.

B. Service-learning improves students' ability to apply what they have learned in "the real world".

C. The impact of service-learning on student academic learning as measured by course grades or GPA is mixed.

D. Service-learning participation has an impact on such academic outcomes as demonstrated complexity of understanding, problem analysis, critical thinking, and cognitive development.

2. Service-learning helps students improve higher order thinking skills:

A. In addition to acquisition of core knowledge and skills, some researchers found that many service-learning tasks help students to improve higher order thinking skills such as analysis, problem solving, decision-making, cognitive complexity, and inferential comprehension because they are exposed to relevant tasks that require them to use these types of skills. Service Learning assists students to "internalize the theories they have learned in courses, begin to think like professionals, and develop practical knowledge."

3. Service-learning fosters the development of important personal and social skills for students:

A. Service-learning, promotes responsibility, trustworthiness, and caring for others. Young people who participate in service-learning are also more likely to acquire an ethic of service and to continue volunteer work as they get older.

B. Moreover, the benefits have been shown to extend even beyond the college years Service-learning has a positive effect on interpersonal development and the ability to work well with others, leadership and communication skills.

4. Career Exploration:

A. Through their service-learning experiences, many students come into contact with adults in careers that would otherwise remain hidden to them.

B. Many companies today expect participation in community service and often look for service activities on potential employee resumes

Social Outcomes:

Recipient of Benefits Community

1. Service-learning has a positive effect on reducing stereotypes and facilitating cultural \& racial understanding. Service-learning has a positive effect on sense of social responsibility and citizenship skills. Service-learning has a positive effect on commitment to service. Volunteer service in college is associated with involvement in community service after graduation.

2. Service-learning helps young adults develop stronger ties to their, communities, and society.

Institutional Outcomes:

Recipient of Benefits: Faculty, Colleges, and Universities

1. Service-learning helps young people develop stronger ties to their college and University. Service-learning improves student satisfaction with college.

2. Service-learning can also establish a sense of civic responsibility to the school, community, and society. Young adults who engage in servicelearning often come to believe that they can make a difference in their schools, communities, and society. They participate in service activities that often have an observable outcome, and they experience personal efficacy.

\section{Sources of Information}

Conrad, and Hedin 1991[44], Dean, and Murdock 1992 [45], Batchelder, and Root 1994 [46], Boss 1994 [47], Hammond 1994 [48], Cohen, and Kinsey 1994 [49], Ridgell 1994 [50], Stanton 1994 [51], Eyler 1997 [52], Miller 1997 [53], Howe 1997 [54], Sax, and Astin 1997 [55], Berkas 1997 [56], Astin, and Sax 1998 [57], Osborne, Hammerich, and Hensley 1998 [58], Dunlap 1998 [59], Leming 1998 [60], Keith 1998 [61], Gelmon 1998 [62], Astin, Sax, and Avalos 1999 [63], Nnakwe 1999 [64], Vernon 1999 [65], Whitfield 1999 [66], Vogelgesang, and Astin 2000 [67], Boyle-Baise, and Kilbane, 2000 [68], Strage 2000 [69], Antonio et al. 2000 [70], Bringle, and Hatcher 2000 [71], Ferrari, and Worrall 2000 [72], Barr, and McNeily 2002 [73]. Papamarcos 2002 [74], Riley 2006 [75], Scott 2008 [76], Spiller 2008 [77], Tomkovick et al. 2008 [78], Flannery, and Pragman 2008 [79], Porter 2008 [80], Jones $2008[81]$.

The Service Performance: the service-learning performance required each student in their group complete 15 hours of service with a nonprofit organization. The project supervisor upon completion of the required number of hours signed a form verifying the task was accomplished.

The Report \& Reflection: each group completed a final written report containing the following sections: explaining the mission of the non-profit organization, services performed by the group, describing in some detail specific examples of how the organization was or was not utilizing key marketing concepts, providing the agency with a set of recommendations as to how they can improve their marketing effort, and finally adding their personal reflection about the experience.
Presentation and Debriefing: one class session at the end of the semester was devoted to group presentations. The groups shared their experiences and feelings about the assignment, as part of that debriefing; a questionnaire was administered to determine the extent to which the desired outcomes were achieved.

The teaching effectiveness of the instructor was measured by the school adopted instrument shown in Table 3. It should be noted that in overwhelming majority of United States universities and colleges during the last week of semesters, it is customary that students should anonymously evaluate their instructor's teaching effectiveness. 
Table 3. The Course Evaluation Instrument

\begin{tabular}{|l|}
\hline \multicolumn{1}{|c|}{ Please rate the instructor on the following characteristics using the scale of 1-5 [Poor (1), Fair (2), Average (3), Good (4), Excellent (5).] } \\
\hline \hline Criterion \# 1: Genuine interest in encouraging high quality student work. \\
\hline Criterion \# 2: Enthusiasm for subject. \\
\hline Criterion \# 3: Ability to communicate the material \\
\hline Criterion \# 4: Ability to elicit questions and good class discussions. \\
\hline Criterion \# 5: Willingness to have students ask questions. \\
\hline Criterion \# 6: Ability to respond to student questions. \\
\hline Criterion \# 7: Overall teaching effectiveness in this course. \\
\hline Criterion \# 8: The course was well-organized and well-presented. \\
\hline
\end{tabular}

The null and alternative hypotheses tested in this study are listed in Table 4.

\section{Qualitative Methodologies}

\section{Focus Group Analysis}

A focus group consisted of 10 students who participated in the PBSL group projects was conducted. The intent was to assess the cognitive outcomes of the project and to encourage students to provide additional insights about their experience. A focus group is a group of interacting individuals having some common interest or characteristics, brought together by a moderator, who uses the group and its interaction as a way to gain information about a specific or focused issue. The moderator created a permissive and nurturing environment that encouraged different perceptions and insights being expressed freely. Careful and systematic analyses of the discussions provided clues and insights to the perception of participants. The interaction between the moderator and the group, as well as the interaction between group members, served to elicit the required information.
The dynamic nature of the questions asked by the moderator and the group process produced a level of insight that is rarely derived from 'unidirectional' information collection instrument such as surveys. The moderator employed a guide to keep the group on track according to a pre-set agenda that was shared with participants at the beginning of the session, the guide helped the conversation develop in line with the research questions.

\section{Content Analysis}

Holsti (1969) has defined the content analysis as "any technique for making inferences by objectively and systematically identifying specified characteristics of messages." The overall purpose of analysis is to determine the presence of key words or concepts within sets of texts. The presence, meanings and relationships of such words and concepts should be examined in order to make inferences about the messages within the texts. There are two general categories of content analysis: "Conceptual Analysis" establishes the existence and frequency of concepts in a text, and "Relational Analysis" builds on conceptual analysis by

Table 4. List of Hypotheses

\begin{tabular}{|c|c|}
\hline Hypotheses 1: PBSL has a positive impact on "Criterion \# 1" & $\begin{array}{l}\mathrm{H} 01: \mu 1(\mathrm{EG})=\mu 1(\mathrm{CG}) \\
\mathrm{HA} 1: \mu 1(\mathrm{EG}) \neq \mu 1(\mathrm{CG})\end{array}$ \\
\hline Hypotheses 2: PBSL has a positive impact on "Criterion \# 2" & $\begin{array}{l}\mathrm{H} 02: \mu 2(\mathrm{EG})=\mu 2(\mathrm{CG}) \\
\mathrm{HA} 2: \mu 2(\mathrm{EG}) \neq \mu 2(\mathrm{CG})\end{array}$ \\
\hline Hypotheses 3: PBSL has a positive impact on "Criterion \# 3" & $\begin{array}{l}\mathrm{H} 03: \mu 3(\mathrm{EG})=\mu 3(\mathrm{CG}) \\
\mathrm{HA} 3: \mu 3(\mathrm{EG}) \neq \mu 3(\mathrm{CG})\end{array}$ \\
\hline Hypotheses 5: PBSL has a positive impact on "Criterion \# 5" & $\begin{array}{l}\mathrm{H} 05: \mu 5(\mathrm{EG})=\mu 5(\mathrm{CG}) \\
\mathrm{HA} 5: \mu 5(\mathrm{EG}) \neq \mu 5(\mathrm{CG})\end{array}$ \\
\hline Hypotheses 6: PBSL has a positive impact on "Criterion \# 6" & $\begin{array}{l}\mathrm{H} 06: \mu 6(\mathrm{EG})=\mu 6(\mathrm{CG}) \\
\text { HA6: } \mu 6(\mathrm{EG}) \neq \mu 6(\mathrm{CG})\end{array}$ \\
\hline Hypotheses 9: PBSL has a positive impact on "Overall Attitude Toward the Teaching Effectiveness" & $\begin{array}{l}\text { H09: } \mu 9(\mathrm{EG})=\mu 9(\mathrm{CG}) \\
\text { HA9: } \mu 9(\mathrm{EG}) \neq \mu 9(\mathrm{CG})\end{array}$ \\
\hline
\end{tabular}

Note: $\mu$ s are the average scores of each criterion for Experimental Group (EG) and Control Group (CG) respectively. 
examining the relationships among concepts in a text. A "Content Analysis" was also performed on the student's written reflection to reveal recurring themes.

\section{QUANTITATIVE FINDINGS}

\section{Quantitative Finding 1}

"The adoption of a well organized Problem-
Based Service-Learning (PBSL)" group project
will positively change the students' perception
of instructor' teaching effectiveness".

To test the hypotheses listed in Table 4, t-tests for equality of means between Experimental and Control Groups were performed. The result of the test is shown in (Appendix A). All null hypotheses (HO1-HO8) were rejected with exception of null hypothesis 3 . The results of $t$-test indicated that, the students who belonged to the "Experimental Group" and were exposed to the PBSL group project, have significantly changed their perception of instructor's teaching effectiveness in 7 out of 8 criterion shown in Table 3, which included: "encouraging high quality student work", "enthusiasm for subject", "ability to elicit questions and class discussions", "willingness to have students ask questions", "ability to respond to student questions", "wellorganized and presented course", and finally "overall teaching effectiveness". However, their perception regarding the instructor's ability to communicate the material was not changed. This finding is not surprising, because the teaching style of an experienced instructor will not change due to adoption of a new project. It is reasonable to assume that throughout the years any instructor will develop a unique teaching style and presentation skill that become part of his/her academic identity and reputation regardless of the topic he/she is teaching.

\section{Quantitative Finding 2}

"The adoption of a well organized PBSL group
project will positively change the students,
overall attitude regarding the instructor's
teaching effectiveness."

To test Hypothesis 9: "PBSL has a positive impact on overall attitude toward the teaching effectiveness", an overall attitude score was calculated by adding up the students responses to questions shown in Table $\mathbf{3}$, then the average attitude scores for both "Experimental Group" (EG), and "Control Group" (CG) was calculated (see Fig. (6) below, and Appendix B). Since the students perception was measured using criterion 1-8, with minimum scale value of 1 , and maximum scale value of 5 , in this scale a total minimum possible score will be 8 , and a total maximum possible score will be 40 . In this continuum any value below 24 indicates that students hold a negative overall attitude toward teaching effectiveness, and any score above 24 indicates students had formed a positive overall attitude toward the teaching effectiveness. Fig. (6) shows that both groups had an overall positive attitude toward the teaching effectiveness, but the attitude score in "Experimental Group" was significantly higher. Since everything else besides the adoption of PBSL group Project was constant in both groups, the change in overall attitude score should be attributed to adoption of PBSL group project. In fact the t-test for equality of two means was rejected (see Appendix C).

\section{Quantitative Finding 3}

"The adoption of PBSL will create a unique
perceptual position in students' mind in relation
to High Quality Student Work Expectation. This
unique perceptual phenomenon simultaneously
will produce a positive carry-over impact on
other aspects of the instructor's perceived
teaching effectiveness.

Since Finding 1 indicated that the adoption of the PBSL group project has positively changed the students' perception of the instructor's teaching effectiveness, and finding 2 reinforced that notion, a factor analysis was conducted to reveal the relationships (underlying factors) among interrelated criterion 1-8 (see Table 3). The factor analysis was performed for both "Experimental Group" (EG) and "Control Group" (CG). Each variable has loaded on one and only one factor (see Appendix D). The examination of the wording of criterion 1-8 was used to name the factors. In Control Group (CG) the three factors were named as: "Teaching Effectiveness (TE)", "Engaging Students (ES)", and "Communication Ability (CA)" respectively. In "Experimental Group" (EG) a very similar pattern of variable loading was observed with the exception of the forth unique factor which was named "High Quality Student Work Expectation". In factor analysis the co-variation among the variables is described in terms of a small number of factors. The first factor accounted for highest variance in the data and the second factor the second highest and so on. The total variance explained by factors identified for Control Group (CG), and Experimental Group (EG), were $77 \%$ and $91 \%$ respectively (see Appendix D).

The comparison of Varimax Orthogonal Rotated Factors for two groups indicated that a set of common underlying factors were presented in both groups. On the other hand in "Experimental Group" a distinctive and unique factor was created in a student's mind that logically should be attributed to the inclusion of PBSL project in the course for Experimental Group. This indicates that the adoption of a high quality PBSL project not only creates a "High Quality Student Work Expectation" in a student's mind, but more interestingly the positive effect of PBSL project has a carryover affect on other aspects of teaching effectiveness.

The key statistics associated with factor analysis are the Barlett's test of Sphericity, and Kaiser-Meyer-Olkin (KMO)

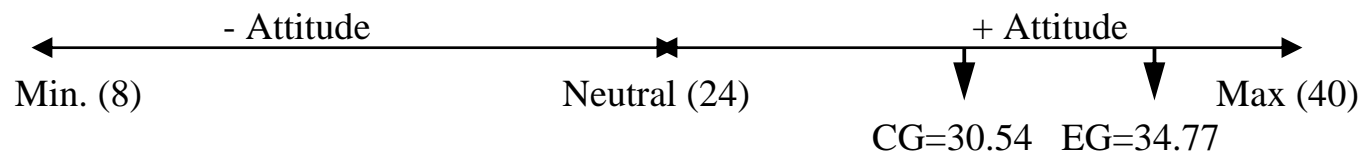

Fig. (6). Average attitude scores for control and experimental groups. 
measure. The test statistic is based on a chi-square transformation of the determinant of correlation matrix. The test indicated that the finding is statistically significant. The Kaiser-Meyer-Olkin (KMO) measure, was used to examine the appropriateness of factor analysis, a high values between 0.5-1.0 indicates the factor analysis is appropriate. The values of KMO statistics were large enough (0.665 and 0.681 ) to indicate that the factor analysis was indeed statistically significant (see Appendix D).

\section{DISCUSSION (QUALITATIVE FINDINGS)}

It was desirable to explore why the inclusion of the PBSL project created a unique factor in a students' mind. To find a persuasive and convincing answer to the above question, as explained in the "Research Design" section of this paper a "Focus Group Study", and a "Content Analysis" on student's two page written reflections was performed. There are two general categories of content analysis: "Conceptual Analysis", and "Relational Analysis". The "Conceptual Analysis" establishes the existence and frequency of key concepts in a text, while the "Relational Analysis" builds on conceptual analysis by examining the relationships among concepts identified in "Conceptual Analysis" in a text (Holsti 1969[84]). First a "Conceptual Analysis" was performed on 320 total reflection pages (two pages per person submitted by 160 students in the "Experimental Group") regarding the PBSL group projects. Using the results of "Conceptual Analysis" a "Relational Analysis" was performed. In this section of the paper the results of Focus Group study and "Conceptual Analysis" will be discussed. Due to its appropriateness (rapping up the discussions), the "Relational Analysis" outcome will be discussed in "Conclusion' section of the paper.

\section{The Focus Group Analysis Results}

A focus Group Study was conducted. In conducting the focus group the moderator tried to scrutinize student's perceptions of PBSL project in order to infer the reasons underlining the creation of unique factor in their mind, and to find out why the participation in PBSL project had a positive carry over impact in regard to instructor's teaching performance. In analyzing the result of focus group, the following factors were taken into consideration. The frequency counts of commonly used words were recorded, and then similar concepts and words were clustered together. The context of words, the changing or reversing the positions after interaction with others was scrutinized. A response that was specific and based on experiences was given more weight than responses that are vague and impersonal. The Examination of the results of focus group provided the following conclusions:

\section{Focus Group Qualitative Finding 1}

"The PBSL group project was perceived as a high quality, well thought-out, structured, and pertinent project by binding the key marketing concepts and tools to a real world situation."

This conclusion is compelling and persuasive, since students make a connection between the services they provided and concepts they studied and learned in the classroom. During the focus group, the following question was asked: "Why did you perceive the PBSL group project as a high quality project?" The majority of participants indicated that compared to other projects in other courses they were taking in the same semester, they were not required to work on such comprehensive project that has demanded so much accountability and quality work. The second reason mentioned was that the supporting materials including the required readings, creating a service learning plan, and having access to forms, and resources posted in service learning web site made the implementation of the project successful. It should be noted that during the first week of the semester one full session (105 minutes) was allocated to explain the role of PBSL group project in the course. The students mentioned that the establishment of following five objectives/outcomes pointed out the fact that they are dealing with a well-thought and quality project:

A) To instill a desire to serve the community.

B) To make students aware of opportunities for career development and employment in the nonprofit sector. Many companies today expect participation in community services and often look for service activities on potential employees' resumes. The social sector provides a wide variety of potential employment opportunities for students studying marketing. An increasing number of nonprofit organizations are adopting common marketing practices and expanding their staffs to include marketing specialists. Most students entering business schools are totally unaware of this trend or these opportunities, through appropriate readings and discussions, students were made aware of the role that community service can play in career development and advancement.

C) To use some of the key marketing concepts and tools in real world situation. By having students work on the PBSL Group Project, students were able to draw on those experiences to see the correlation and interconnectedness of the project to marketing principles and tools. The examples of applying marketing tools and concepts included the creation of databases of potential donors, development of promotional flyers and newsletters, the creation and execution of fund-raising events, or designing, implementing, and analyzing market research.

D) To create greater sensitivity toward diversity. Many community agencies dealt with individuals from different cultures, social and educational backgrounds, and economic circumstances. As a result, the service-learning project provided students with the challenge to effectively work with people who have a completely different background.

E). To enhance their leadership, team work, and communication skills. The ability to assist others resulted in a boost in the individual's self esteem. Many students did not realize just how valuable an asset they can be for a struggling community service agency.

To assist students a website dedicated to the ServiceLearning Project was developed. The website was designed to make the entire Service-Learning project more positive and a productive experience for students and its community 
partners, the objective was to make the website interesting, informative, and user-friendly. Students believed that all supporting materials included in the web site (e.g., Service Learning Action Plan, and Forms,) did facilitate the smooth implementation of the project and more importantly sent a set of signals that a high level of accountability is expected in this project. The web site had the following components:

$\S \quad$ Required Readings: two articles were assigned to make the students familiarize with the concept of servicelearning: "Eight Characteristics of Nonprofit Organizations" Allison [62], and "Service Learning Everybody Wins!" (Written by the coordinator of various sections of principle of marketing course.)

$\S$ The Service learning Action Plan: As a group students, with collaboration of the project supervisor were asked to develop an "Action Plan". The plan contained specific marketing-related objectives the students will be engaged in and the expected outcomes they will accomplish for this project. The General guidelines as to the frequency with which students must be available, description of any special skills student(s) must have (bi-lingual, computers, etc.).

$\S$ Service Organization Commitment: The CBO committed itself for meeting with students in a timely manner and on a periodic basis for progress reviews, providing the necessary business background and current operational information, and agreeing to guide the student's work, and to submit a brief final evaluation of their achievement.

$\S \quad$ Student Commitment: students agreed to abide by the following guidelines: asking for help from your site supervisor or professor when in doubt, being punctual and responsible, showing respect for the communitybased organization, treating the supervisor and others with courtesy and kindness, dressing neatly and appropriately, and being flexible.

$\S$ Student Evaluation of Service-Learning CBO: Students evaluation of your service-learning placement site was done by students agreeing or disagreeing in terms of: whether or not the site provided an orientation session that familiarized them with the agency, its mission and clients, if their time (15 hours per member) was used effectively. If students had enough contact with project supervisor, and if other staff were supportive of students, and their work at the agency was appreciated, and finally they were encouraged to make suggestions to improve the agency's efficiency.

$\S \quad$ Site Supervisor Evaluation of students Performance: The overall quality of the student's efforts, their level of interest in the project, their ability to take direction and work with little supervision, working well with the rest of the staff, showing up on time for scheduled meetings, and finally their overall performance was assessed by the site supervisor.

$\S \quad$ Peer Evaluation of Team Members: Each team member completed a questionnaire, rating the performance of their teammates and their contributions to the group project. The ratings and comments made by each member were used to help the instructor evaluate the performance of each student and assign individual grades for the project.

$\S \quad$ Press Release Assignment: each team was required to follow a press release standard guideline to prepare a press release that could be used to publicize the services they have rendered for CBO.

\section{Focus Group Qualitative Finding 2}

"Students felt they were meaningfully contributing to the welfare of community."

Students attributed the above conclusion to a briefing meeting that took place at the beginning of the semester and the outcomes of their team effort dedicated to the CBOs at the end of semester. In the briefing session, at the beginning of the process, students were told that Community-base Organizations (CBOs) perform indispensable job with minimum financial, and manpower recourses. CBOs welcomed student's resources and expertise and treated students as consultants who were willing to help them to achieve their objectives. Students were coached that they should have not underestimated themselves and their marketing knowledge, even though they were learning the principles of marketing for the first time by taking this course. Students were also told that they were trusted to play the role of marketing consultants for a non-profit organization that lacked the marketing knowledge. They were also advised that the principles of marketing is applicable to these organizations as they attempt to develop sustainable relationships with clientele, donors, volunteers, funding organizations, government agencies, and the general public. When approaching CBOs, they were expected to act professionally and act as a university ambassador. The Group coordinators were required to communicate with the instructor regularly about the progress toward achieving the project objectives. This sense of responsibility created a very positive image about the project and boosted students' selfrespect and self-confidence significantly.

\section{"Conceptual Analysis" Results}

Holsti (1969 [84]) has suggested that in "Conceptual Analysis" the researcher simply wants to examine whether there is a stronger presence of positive or negative key concepts with respect to respective arguments, by breaking down the contents of materials into meaningful and pertinent units of information (key concepts), certain characteristics of the overall message could inferred. Following that recommendation the analysis focused only on quantifying the key words and themes and not in examining how they were interrelated, which was the focus of "Relational Analysis". The reflection journals of students were carefully examined and analyzed. The "topical codes" method was utilized which required that each sentence be coded for major issues. Seven primary themes emerged which are shown in Table $\mathbf{5}$ and discussed below.

Making a Positive Impact on Local Community: The experience gave students a sense of belonging to the local community. They became proud that they were able to make a difference and accomplish something meaningful and consequential. 
Table 5. The Result of "Conceptual Analysis" of Reflection Journals

\begin{tabular}{|c|c|}
\hline \% of Students in "Experimental Group" who Expressed the Following or Similar Point of Views and Perspectives & $\%$ \\
\hline 1. I made a positive impact on local community. & $18 \%$ \\
\hline 2. The PBSL group project had a positive impact on my character building and personal skill development. & $17 \%$ \\
\hline 3. I became aware of marketing role in Community Based Organizations. & $15 \%$ \\
\hline 4. I will make a long-term commitment to participate in this type of community-based projects. & $14 \%$ \\
\hline 5. I developed an excellent perception regarding this experience. & $13 \%$ \\
\hline 6. I became aware of society needs. & $12 \%$ \\
\hline 7. I enjoyed the group interaction and dynamic. & $11 \%$ \\
\hline Total & $100 \%$ \\
\hline
\end{tabular}

Having A Positive Impact On Character Building And Personal Skill Development: The students completely enjoyed this experience because it gave them a higher level of self-confidence that they can make a difference in their community while they were developing the character and personal skills.

Becoming Aware of Marketing Role in Community Based Organizations: According to students the project gave them a great opportunity to see how marketing plays a vital function in Community Based Organizations in order to survive and achieve their goals. They came out with a new respect for the power of marketing to practice some marketing concepts because they were able to see the connection between marketing and non-profit organizations. The academic aspect of this experience showed them how to apply concepts they did learn during this course and witnessing its positive impact on community.

Long-term Commitment to Engage in Communitybased Types of Projects: The overwhelming majority of students indicated that without a doubt they will continue to volunteer and serve my community again.

Developing Excellent Perception Regarding the Experience: Overall, the majority of students developed an excellent perception about the project because they enjoyed this experience and thought, the project contributed meaningfully to their sense of belongingness to local community while having hands on experience and observing marketing in action.

Becoming Aware of Society Needs: Becoming aware of the needs of community and making others aware too, was a recurring themes shared by many students who participated in this project.
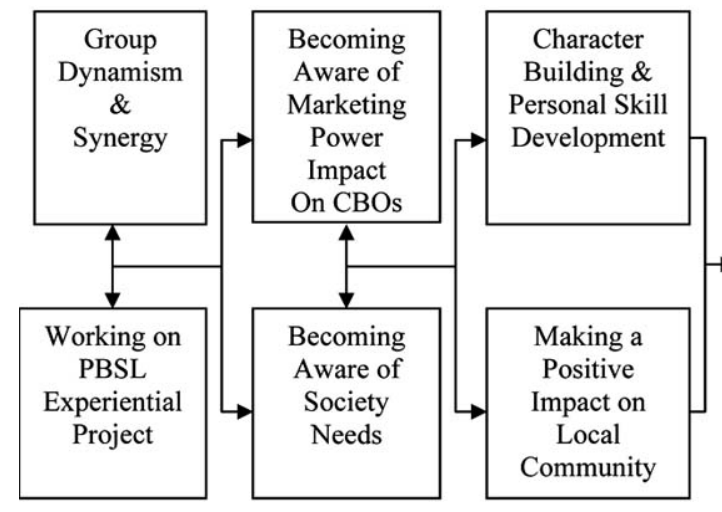

Enjoying Group Dynamic and Synergy: Almost all students enjoyed the group meetings and being able to work with other students with different backgrounds and to hear other students' ideas and opinions

\section{CONCLUSION}

The result of this experimental study, and subsequent analysis of "Focus Group" study, and "Content Analysis" of students' reflection journals strongly points out the following conclusions:

1. The inclusion of a well-planed PBSL group project in a principle of marketing course, in addition to creating a unique and distinguishable factor in a student's mind regarding civic engagement, will positively change their perception of the instructor's teaching effectiveness too.

2. If the project is to be perceived as a high-quality and educational project by students, the necessary resources including all relevant information, readings, plans, and forms should carefully be created with easy access to them (e.g., via a website).

3. The PBSL group project objectives needed to be carefully specified and have specific outcomes that can be accomplished and measured in the allotted time.

4. The communication between the agency, faculty, and students is extremely critical. Most of the unsuccessful projects have resulted from a lack of contact, communication, feedback, or responsiveness on the part of one of these parties. Agencies should designate one individual as a contact and mentor who

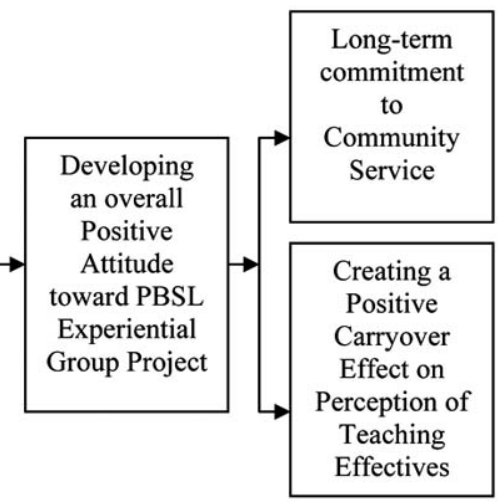

Fig. (7). Relational analysis. 
can be flexible in their availability. Agencies are discouraged from attempting multiple projects during the same semester. Trying to work with several student teams or individuals on different projects at the same time is difficult to coordinate and the results are usually unsatisfactory for all parties.

5. The PBSL group project has a positive impact on developing and enhancing students' leadership and communication skills, and the ability to work well with others in the group while reducing stereotypes and facilitating cultural and racial understanding. In addition the participation in the PBSL group project has a positive effect on sense of social responsibility, spiritual growth, moral development, and on commitment to community service and more importantly increased probability of involvement in community service after graduation.

6. Application of knowledge: the PBSL had a positive impact on students' academic learning, the majority of students in their reflection indicated that compared to traditional assignments in other marketing courses, this project was more useful in placing classroom material in a meaningful context and improving their ability to apply what they have learned in "the real world". The majority of students also reported that the PBSL project strengthened their understandings of class lectures. They also reported that learning exercises were more effective and more learning occurred than in traditional courses, and that projects placed learning in a more meaningful context than did other assignments.

7. Students in their reflection journals indicated an overwhelming positive response to the learning experience, and they experienced significant increases in their beliefs that people can make a difference and that they should be involved in community service.

8. Relational Analysis: As it was mentioned in the previous section, the "Relational Analysis" seeks to explore the relationships between the concepts identified in "Conceptual Analysis". An attempt was made to represent the relationships visually. The following "Relational Analysis" graphic representation was created by synthesizing the quantitative and qualitative findings of this study. The chart can be perceived as a proposed conceptual model which indicates how long-tern commitment to community service is crated and instilled in student's mind.

Fig. (7) indicates that Students' participation in a well designed and integrated PBSL experiential project, in conjunction with group dynamism, creates a heightened level of awareness regarding the society needs in general and the beneficial roles which CBOs play in particular. Students attach an ever-increasing importance to their hands-on experience, and become aware of reciprocity between what they contributed to $\mathrm{CBO}$ and the service recipients. The perception of making a positive impact on the community, in turn will create an increased sense of efficacy and personal character and skill development which in turn creates a long lasting positive attitude toward the experiment. The final outcome of the process is the creation of a positive carryover on perception of teaching effectiveness of the instructor. The students' reflections indicated that an instructor who has put so much time to create and supervise this type of engaging activity and resources should have taken other aspects of teaching seriously too.

\section{APPENDIX A}

\section{t-tests for Equality of Means}

\begin{tabular}{|l|l|l|l|l|}
\hline & \multicolumn{1}{|c|}{$\mathbf{t}$} & \multicolumn{1}{|c|}{ df } & Sig & \multicolumn{1}{|c|}{ Conclusion } \\
\hline \hline $\begin{array}{l}\text { Hypothesis 1, Criterion \# 1: Genuine interest in encouraging high quality student } \\
\text { work. }\end{array}$ & -4.205 & 303 & .000 & The Null hypothesis was rejected \\
\hline Hypothesis 2, Criterion \# 2: Enthusiasm for subject. & -6.588 & 303 & .000 & The Null hypothesis was rejected \\
\hline Hypothesis 3, Criterion \# 3: Ability to communicate the material & .471 & 303 & .638 & The Null hypothesis was not rejected \\
\hline Hypothesis 4, Criterion \# 4: Ability to elicit questions and good class discussions. & -12.598 & 303 & .000 & The Null hypothesis was rejected \\
\hline Hypothesis 5, Criterion \# 5: Willingness to have students ask questions. & -9.984 & 303 & .000 & The Null hypothesis was rejected \\
\hline Hypothesis 6, Criterion \# 6: Ability to respond to student questions. & -11.697 & 303 & .000 & The Null hypothesis was rejected \\
\hline Hypothesis 7, Criterion \# 7: Overall teaching effectiveness in this course. & -6.756 & 303 & .000 & The Null hypothesis was rejected \\
\hline Hypothesis 8, Criterion \# 8: The course was well-organized and well-presented. & -6.897 & 303 & .000 & The Null hypothesis was rejected \\
\hline
\end{tabular}

APPENDIX B

Mean Overall Attitude Scores for Control and Experimental Groups

\begin{tabular}{|c|c|c|c|c|}
\hline $\begin{array}{c}\text { Hypothesis 9: PBSL has a Positive Impact on "Overall Attitude Score" } \\
\text { About teaching effectiveness" }\end{array}$ & $\mathbf{n}$ & $\begin{array}{l}\text { Overall Attitude } \\
\text { Score (Mean) }\end{array}$ & $\begin{array}{c}\text { Std. } \\
\text { Deviation }\end{array}$ & $\begin{array}{l}\text { Std. Error } \\
\text { Mean }\end{array}$ \\
\hline Control Group & 160 & 30.5438 & 3.06091 & .24199 \\
\hline Experimental Group & 145 & 34.7793 & 2.55623 & .21228 \\
\hline
\end{tabular}




\section{APPENDIX C}

\section{t-test for Equality of Attitude Means}

\begin{tabular}{|c|c|c|c|}
\hline & $\mathbf{t}$ & df & Sig. (2-Tailed) \\
\hline \hline Attitude & -13.043 & 303 & .000 \\
\hline
\end{tabular}

\section{APPENDIX D}

\section{Varimax Orthogonal Rotated Factors}

\begin{tabular}{|c|c|c|c|c|c|c|c|}
\hline \multirow[b]{3}{*}{ Variables (Coming from Table 3) } & \multicolumn{3}{|c|}{ Control Group } & \multicolumn{4}{|c|}{ Experimental Group } \\
\hline & \multicolumn{3}{|c|}{ Factors } & \multicolumn{4}{|r|}{ Factors } \\
\hline & TE & ES & CA & TE & ES & CA & High Quality Student Work Expectation \\
\hline V1. High Quality Student Work Expectation & .887 & & & & & & .998 \\
\hline V2. Faculty Enthusiasm for Subject & .903 & & & .932 & & & \\
\hline V3. Overall Teaching Effectiveness & .894 & & & .977 & & & \\
\hline V4. Well-Organized & .844 & & & .954 & & & \\
\hline V5. Eliciting Class Discussion & & $\begin{array}{c}.92 \\
8\end{array}$ & & & .839 & & \\
\hline $\begin{array}{l}\text { V6. Willingness to have Students Ask } \\
\text { Questions }\end{array}$ & & $\begin{array}{l}.92 \\
8\end{array}$ & & & .963 & & \\
\hline $\begin{array}{l}\text { V7. Faculty Ability to respond to Students } \\
\text { Questions }\end{array}$ & & & .864 & & .957 & & \\
\hline V.8 Faculty Communication Ability & & & .665 & & & .997 & \\
\hline
\end{tabular}

$\mathrm{TE}=$ Teaching Effectiveness

$\mathrm{ES}=$ Engaging Students.

$\mathrm{CA}=$ Communication Ability.

Rotation Method: Varimax with Kaiser Normalization, rotation converged in 4iterations.

\section{Total Variance Explained}

\begin{tabular}{|c|c|c|}
\hline Factors & Control Group Cumulative \% & Experimental Group Cumulative \% \\
\hline \hline 1 & 40.253 & 34.287 \\
\hline 2 & 61.885 & 66.222 \\
\hline 3 & 77.407 & 78.887 \\
\hline 4 & - & 91.390 \\
\hline
\end{tabular}

Extraction Method: Principal Component Analysis.

\section{KMO and Bartlett's Test}

\begin{tabular}{|c|c|c|}
\hline & Control Group & Experimental Group \\
\hline \hline Kaiser-Meyer-Olkin Measure of Sampling Adequacy. & 0.665 & .681 \\
\hline Bartlett's Test of Sphericity Approx. Chi-Square & 739.362 & 987.881 \\
\hline $\mathrm{df}$ & 28 & 28 \\
\hline Sig. & .000 & .000 \\
\hline
\end{tabular}




\section{REFERENCES}

[1] Hesser G. Faculty assessment of student learning: Outcomes attributed to service-learning and evidence of changes in faculty attitudes about experiential education. Michigan. J Commun Service Learn 1995; 2 : 33-42.

[2] Klink R, Athaide G. Implementing service learning in the principles of marketing course. J Market Educ 2004; 26: 145-53.

[3] Sigmon R. Serving to Learn. Learning to Serve. Linking Service with Learning. Council for Independent College Report 1994.

[4] Driscoll A, Holland B, Gelmon S, Kerrigan S. An assessment model for service-learning: comprehensive case studies of impact on faculty, students, community, and institutions. Michigan J Commun Service Learn 1996; 3: 66-71.

[5] Evangelopoulos N, Sidorova A, Riolli L. Can service-learning help students sppreciate an unpopular course?: A theoretical framework. Michigan J Commun Service Learn 2003; 9: 15-24.

[6] Hagenbuch D. Service learning inputs and outcomes in a personal selling course. J Market Educ 2006; 28: 26-34.

[7] Driscoll A. Studying faculty and service-learning: Directions for inquiry and development. Michigan $\mathrm{J}$ Commun Service Learn 2000, Special Issue.

[8] Abes E, Jackson G, Jones S. Factors that motivate and deter faculty use of service-learning. Michigan J Commun Service Learn 2002; 9: 5-17.

[9] Pribbenow D. The impact of service-learning pedagogy on faculty teaching and learning. Michigan J Commun Service Learn 2005; 11: 25-38.

[10] Peirce C. Selected writings. In: Wiener PP, Ed. Dover Publications 1966.

[11] James W. Pragmatism. Dover Publications: New York 1995.

[12] Dewey J. Experience and education. New York: Collier Books 1963.

[13] Stuhr J, Ed. Pragmatism and classical American philosophy: essential readings and interpretive essays. $2^{\text {nd }}$ ed. New York: Oxford University Press 2000.

[14] Neill J. Experiential learning \& experiential education philosophy Theory, Practice \& Resources [online] 2004, [Cited 7/15/2009]. Available from: http://www.wilderdom.com/experiential/elc/Experi entialLearningCycle.htm

[15] Bacon S. The evolution of the outward bound process [online]. 1987, [cited 7/15/2009]. Available from: http://www.wilderdom. com/experiential/elc/ExperientialLearningCycleReferences.htm\#Ba con

[16] James T. Can the mountains speak for themselves? Colorado Outward Bound. 1980. Retrieved 7/15/2009. [Cited7/15/2009]. Available from: http://www.wilderdom.com/facilitation/Mountains. html

[17] Greenaway R. Experiential learning cycles [online]. 2002, [Cited7/15/2009]. Available from: http://www.wilderdom.com/exp eriential/elc/ExperientialLearningCycleReferences.htm\# Greenaway2002b

[18] Kolb D. Experiential learning: Experience as the source of learning and development. NJ: Prentice-Hall 1984.

[19] Kelly G. Theory of personality: The psychology of personal constructs. W.W. Norton: New York 1995.

[20] Pfeiffer W, Jones J. A handbook of structured experiences for human relations training. University Associates: La Jolla, CA 1975; vol. 1-5.

[21] Priest S. Everything you always wanted to know about judgment, but were afraid to ask. J Adventur Educ Outdoor Leadership 1990; 7: 5-12.

[22] Eyler J, Giles D. Where's the learning in service-learning? San Francisco; Jossey-Bass Publishers 1999.

[23] Hmelo-Silver C, Barrows E. Goals and strategies of a problembased learning facilitator. Interdisciplinary J Problem-Based Learn 2006; 1: 21-39.

[24] Merrill M. A pebble-in-the-pond model for instructional design. Perform Improve 2002; 41: 39-44.

[25] Massa N. Problem-Based Learning (PBL): A real-world antidote to the standards and testing regime. N Engl J Higher Educ 2008; 22: 19-20.

[26] Bransford J, Brown A, Cocking R, Eds. How people learn: Brain mind experience and school. National Academic Press: Washington DC 2000.

[27] Spronken-Smith R, Harland T. Learning to teach with problembased learning. Active Learn Higher Educ 2009; 10: 138-53.
[28] Bjerkaker S. The study circle for learning and democracy. Convergence 2006; 39: 49-60.

[29] Alderman B. Get real! collaborative learning in higher education. J Austr Assoc Writing Prog 2000; 4: 1

[30] Gokhale A. Collaborative learning enhances critical thinking. J Technol Educ 1995; 7: 22-30.

[31] Mukaddes E. Effects of learning style profile of team on quality of materials developed in collaborative learning processes. Active Learning Higher Educ 2009; 10: 154-71.

[32] Kumpulainen K, Kaartinen S. The interpersonal dynamics of collaborative reasoning in peer interactive dyads. J Exp Educ 2003; 71: 333-70.

[33] National Service-Learning Clearinghouse. History of ServiceLearning in Higher Education [Online]. January 2008. Available from: http://www.servicelearning.org/

[34] Sigmon R. Service-learning: Three principles. Synergist 1979; 8: 911 .

[35] Kendall J. Combining service \& learning a resource book for community and public service, Raleigh. Natl Soc Internship Exp Educ 1990; 2: 20.

[36] Furco A. Service-learning: A balanced approach to experiential education. In Barbara Taylor ed. Expanding boundaries: Serving and learning. Washington DC: Corporation for National Service 1996; pp. 2-6.

[37] Govekar M, Meemakshi R. Service learning: Bringing real-world education into the B-School classroom. J Educ Bus 2007; 83: 3-11.

[38] National Society for experiential education. Partial list of experiential learning terms and their definitions. Raleigh: North Carolina 1994.

[39] Petkus E. Enhancing the relevance and value of marketing curriculum outcomes to a liberal arts education. J Market Educ 2007; 29: 39-51.

[40] Eyler J. What do we most need to know about the impact of service-learning on student learning? Michigan J Commun Service Learn. Specia Issue 2000; pp. 11-7.

[41] Eyler J, Giles D, Stenson M, Gray C. At a glance: What we know about the effects of service- learning on college students. Faculty, Institutions and Communities 1993-2000; Vanderbilt University Press 2001.

[42] Shaw D. Building sales competencies through service learning. Mark Educ Rev 2007; 7: 40

[43] Lopez T, Lee R. Five principles of workable client-based projects: Lessons from the trenches. J Market Educ 2005; 27: 172-88.

[44] Conrad D, Hedin D. School-based community service: What we know from research and theory", Phi Delta Kappan 1991; 72: 7439.

[45] Dean L, Murdock S. The effect of voluntary service on adolescent attitudes toward learning. J Volunteer Admin 1992; Summer: 5-10.

[46] Batchelder T, Root S. Effects of an undergraduate program to integrate academic learning and service: cognitive. Prosocial cognitive, and identity outcomes. J Adolescence 1994; 17: 341-55.

[47] Boss J. The effect of community service on the moral development of college ethics students. J Moral Dev 1994; 23: 83-198.

[48] Hammond C. Integrating service and academic study: Faculty motivation and satisfaction in Michigan higher education Michigan J Commun Service Learn 1994; 1: 21-8.

[49] Cohen J, Kinsey D. Doing good and scholarship: A servicelearning study. J Educator 1994; 48: 4-14.

[50] Ridgell C. Students' perceptions before and after student servicelearning. The Grantmakers' Forum Community and National Service Research Task Force Report. Bloomington, IN: University of Indiana 1994

[51] Stanton T. The experience of faculty participants in an instructional development seminar on service-learning. Michigan J Commun Service Learn 1994; 1: 21-8

[52] Eyler J, Giles D, Braxton J. The impact of service-learning on college students. Michigan J Commun Service Learn 1997; 4: 5-15.

[53] Miller J. The impact of service-learning experiences on students sense of power. Michigan J Commun Service Learn 1997; 4: 6-21.

[54] Howe H. Acting and understanding what service-learning adds to our academic future. Educ Week 1977; April: 56.

[55] Sax L, Astin A. The benefits of service: Evidence from undergraduates. Educ Record: Summer-Fall 1997; 25-33.

[56] Berkas T. Strategic review of the W. K. Kellogg Foundation's Service-Learning Projects. Battle Creek. MI: W. K. Kellogg Foundation 1990-1996. 
[57] Astin A, Sax L. How undergraduates are affected by service participation. J College Student Dev 1998; 39: 251-63.

[58] Osborne R, Hammerich S, Hensley C. Student effects of service learning: Tracking change across a semester. Michigan J Commun Service Learn 1998; 5: 5-13.

[59] Dunlap M. Adjustment and developmental outcomes of students engaged in service learning. J Exp Educ 1998; 21: 147-53.

[60] Leming J. Adding value to service-learning projects. Insights on Global Ethics 1998; Autumn: 7.

[61] Keith Novella Z. Community service for community building: The school-based service corps as border crossers. Michigan J Commun Service Learn 1998; 5: 86-96.

[62] Gelmon S, Holland B, Seifer S, Shinnamon A, Connors K. Community-university partnerships for mutual learning. Michigan J Commun Service Learn 1998; 5: 97-107.

[63] Astin A, Sax L, Avalos J. Long-term effects of volunteerism during the undergraduate years. Rev of Higher Educ 1999; 22: 187-202.

[64] Nnakwe J. Implementation and impact of college community service and its effect on the social responsibility of undergraduate students. J Fam Consumer Services 1999; 9: 57-61.

[65] Vernon A, Ward K. Campus and community partnerships: Assessing impacts \& strengthening connections. Michigan J Commun Service Learn 1999; 6: 30-7.

[66] Whitfield T. Connecting service- and classroom-based learning: The use of problem-based learning. Michigan J Commun Service Learn 1999; 6: 106-111

[67] Vogelgesang L, Astin A. Comparing the effects of service-learning and community service. Michigan J Commun Service Learn 2000; 7: 25-34.

[68] Boyle-Baise M, Kilbane J. What really happens? A look inside service learning for multicultural teacher education. Michigan J Commun Service Learn 2000; 7: 54-64.

[69] Strage AA, Service-learning: Enhancing student learning outcomes in a college-level lecture course. Michigan J Commun Service Learn 2000; 7: 5-13

[70] Antonio A, Astin H, Cress C. Community service in higher education: A look at the nation's faculty. Rev Higher Educ 2000; 23(4): 373-97.

[71] Bringle R, Hatcher J. Institutionalization of service-learning in higher education. J Higher Educ 2000; 71: 273-90.
[72] Ferrari J, Worrall L. Assessments by community agencies: How "the other side" Sees Service-Learning. Michigan J Commun Service Learn 2000; 7: 35-40.

[73] Barr T, McNeilly L. The value of students Classroom experiences from the eyes of the recruiter: Information, implications, and recommendations for marketing educators. J Mark Educ 2000; 24: 168-72.

[74] Papamarcos S. The next wave in service learning: Interpretive, team-based engagements with structural objectives. Rev Bus 2002; 23: $31-8$

[75] Riley K. Service-learning evaluation projects: a step-by-step guide. J Phys Educ 2006; 77: 39-45.

[76] Scott J. The practice of usability: Teaching user engagement through service-learning. Tech Commun Q 2008; 17: 381 .

[77] Spiller L, Scovotti C. Curriculum currency: Integrating direct \& interactive marketing content in introductory marketing courses. J Mark Educ 2008, 30: 66-81.

[78] Tomkovick C, Lester S, Flunker L, Wells T. Linking collegiate service-learning to future volunteerism. Nonprofit Manage Leadership 2008; 19: 3-26.

[79] Flannery B, Pragman C. Working towards empirically-based continuous improvements in service learning. J Bus Ethics 2008; 80: 465-79.

[80] Porter J, Summers M, Toton S, Aisenstein H. Service-learning with a food stamp enrollment campaign: community and student benefits. Michigan J Commun Service Learn 2008; 14: 66-75.

[81] Jones S, Segar T, Gasiorski A. A double-edged sword: College student perceptions of required high school service-learning. Michigan J Commun Service Learn 2008; 15:

[82] Cone R. Six models of service learning. In: Heffernan K, Ed. Fundamentals of service-learning course construction. Providence, RI: Campus Compact 2001.

[83] Allison M, Kaye J. Eight characteristics of nonprofit organizations [Online]. Compass Point (Cited 2009); Available from: http://www.compasspoint.org/askgenie/index.php?vanity_url=op_8 characteristics.html

[84] Holsti Ole. Content analysis for the social sciences and humanities. Reading MA: Addison-Wesley 1969.

(C) Reza Motameni; Licensee Bentham Open.

This is an open access article licensed under the terms of the Creative Commons Attribution Non-Commercial License (http://creativecommons.org/licenses/ by-nc/3.0/) which permits unrestricted, non-commercial use, distribution and reproduction in any medium, provided the work is properly cited. 